icals, common salt will kill barberry if applied to the crowns of European plants in sufficient quantity (about $20 \mathrm{lb}$. per square foot of crown). Native bushes will succumb if the salt is merely sprinkled lightly on the ground around the canes.

\section{National Certificates in Applied Physics}

A PAMPHIET recently issued by the Institute of Physics describes the purpose, scope and value of the courses leading to the award of national certificates in applied physics. It is pointed out that every professional physicist employed in research and development requires two or three technical assistants who need to have a knowledge of the fundamentals of physics and some skill in experimental technique and in making apparatus and instruments. It is for these assistants that the certificates are intended. They are awarded jointly by the Ministry of Education and the Institute of Physics. Study is part-time, extending for the ordinary certificate over three years, and for the higher certificate over a further two years of advanced study, and reaching a standard approximating to that of a university degree at pass standard in the subject. Students attend at recognized technical colleges. The examinations on which the certificates are awarded are assessed by senior members of the profession appointed by the Institute of Physics. Copies of examination papers set in recent examinations are now available and may be obtained from the Institute of Physics, 47 Belgrave Square, London, S.W.1.

\section{University of London}

THe following have been appointed to University of London readerships tenable at University College in the subjects indicated: Mr. Michael Abercrombie, embryology; Dr. E. H. S. Burhop, physics; Mr. J. W. Whitfield, psychology. The degree of D.Sc. has been conferred on the following: B. Kassanis (Rothamsted Experimental Station), Dr. H. O. Schild (University College), R. Kingslake (Imperial College of Science and Technology), E. C. Humphries (Queen Mary College), J. J. D. King (King's College Hospital Medical School), and C. N. Davies (external student).

\section{University of Leeds}

THE following gifts, among others, have been received by the University of Leeds: sums not exceeding $£ 4,000$ in $1950-51$ and $£ 5,000$ in $1951-52$, from the University Grants Committee, for financial assistance to students taking postgraduate courses in the Departments of Fuel and of Textile Industries; $£ 12,000$ (approximately) over three years from the Department of Scientific and Industrial Research to the Department of Botany for research in plant biophysics ; $£ 6,000$ (approximately) over three years from the Agricultural Research Council to the Department of Botany for new biochemical research; $£ 1,000$ from the North-Eestern Division of the National Coal Board to the Department of Mining; an annual sum of $£ 2,000$ (less tax) for fifteen years from the Worshipful Company of Clothworkers, for the maintenance or benefit of the Clothworkers' Departments; and a renewal by Imperial Chemical Industries, Ltd., of the covenant for the endowment of fellowships for a further seven years, the value of the fellowships to be increased from $£ 600$ to $£ 800$ a year. Dr. J. H. Western has been appointed senior lecturer in agricultural botany in the University, and the following have been made lecturers in the subjects as indicated: A. D. Greenwood (botany), Dr. L. Peters (textile industries), Dr. A. Jowett (dressing of minerals, in the Department of Mining) and Dr. D. E. Nicholson (bacteriology).

\section{Announcements}

The Committee of the Privy Council for Agricul. tural Research and Nature Conservation has appointed Dr. Norman C. Wright, chief scientific adviser of the Ministry of Food, to be a member of the Agricultural Research Council.

Prof. F. A. VIck, professor of physics, has been appointed vice-principal of the University College of North Staffordshire. The following have been made lecturers in the College: Dr. R. G. Evans (biology) and Dr. P. H. Plesch (chemistry).

LORD REITH has been appointed chairman of the Colonial Development Corporation in succession to Lord Trefgarne, whose resignation took effect on October 31.

Mr. D. W. Bishopp, director of the Geological Survey of Ireland since 1940, has resigned. He has now been appointed senior geologist to the Cyprus Government, which is initiating a detailed geological and mineralogical survey, including geophysical research, of the island.

The gold medal of the Society of Dyers and Colourists has been awarded to Dr. S. M. Neale, senior lecturer in physical chemistry in the College of Technology, Manchester. The award was made "For pioneer work in the application of the methods of physical chemistry to the elucidation of the phenomena of dyeing, more particularly of cellulosic materials with substantive dyes".

TнE first British Instrument Industries' Exhibition will be held in the National Hall, Olympia, during July 4-14, 1951. Coinciding with the Festival of Britain year, this Exhibition will show scientific and industrial instruments of entirely British manufacture and is designed to increase the export market. Further details can bo obtained from the organisers, Messrs. F. W. Bridges and Sons, Ltd., Grand Build. ings, Trafalgar Square, London, W.C.2.

The nineteenth Stephen Paget Memorial Lecture of the Research Defence Society will be delivered by Prof. E. D. Adrian on November 22, at 5.30 p.m., at University College, Gower Street, London, W.C.1. Prof. Adrian will speak on "Experiments on the Nervous System".

THE first Trotter-Patterson Memorial Lecture of the Illuminating Engineering Society is to be given by Dr. J. W. T. Walsh, of the National Physical Laboratory, at the Royal Institution, Albemarle Street, London, W.1, on January 17, at 6 p.m. Dr. Walsh will speak on "The Early Years of Illuminating Engineering in Great Britain". The Lecture is open to the public and admission will be by ticket, obtainable from the Secretary, Illuminating Engineering Society, 32 Victoria Street, London, S.W.1.

IN the last paragraph of the review, published in Nature of October 14, p. 620, of Corner's "A Monograph of Clavaria and Allied Genera", the comment that only one specimen of a clavaroid fungus has been sent to the Kew Herbarium in the past thirty years is incorrect; for 'Kew' read 'Commonwealth Mycological Institute'. In fact, $K_{\theta w}$ Herbarium, where the group has been studied, has numerous examples of Clavaria. 